\title{
Influence of Utilization of Alternative Dispute Resolution Mechanisms by Leaders on Sustainable Conflict Resolution in Bungoma County, Kenya
}

\author{
Atemi Amele Justin
}

\begin{abstract}
The purpose of this study was to assess the influence of utilization of alternative dispute resolution mechanisms by leaders on sustainable conflict resolution in Bungoma county, Kenya. The study focused on identifying the various types of conflicts in Lwandanyi,Webuye and Cheptais Sub-Counties and the factors influencing the adoption of Alternative Dispute Resolution Mechanisms with specific focus on mediation. The study explored the place of ADR in conflict resolution and the extent to which ADR is utilized by leaders. The sample size was comprised of grass root leaders. Simple random sampling and stratified random sampling methods were used to pick the required sample size for the study from the targeted population. The required data was collected using questionaires and interview schedules. The study found that leaders in Bungoma County appreciate and make use of ADR mechanisms in conflict resolution. Mediation mechanism was commonly cited as being used by leaders in addressing various forms of conflict. The study also found that land disputes are the commonest of all conflicts. This was attributed to historical land injustices especially in Mt. Elgon region where politicization of land allocations in the former white settler farms has led to long standing conflict between the Bukusu and the Sabaot communities. The study also revealed that most land disputes were arising due to lack of land ownership documents and rampant corruption at the lands' ministry was blamed for this state of affairs. Based on the study findings, it was recommended that the National and County governments take decisive action to address the land grievances of the Sabaot community to stop the inter clan fighting and leaders be trained and equipped with skills and competencies necessary for conflict resolution.
\end{abstract}

Keywords: Alternative Dispute Resolution, Leaders, Sustainable Conflict Resolution

DOI: $10.7176 /$ PPAR/11-6-06

Publication date:July $31^{\text {st }} 2021$

\subsection{Background}

The modern world is a world full of chances and options for people. Never before in history so many choices could and had to be made by the individual. But the modern world is also a world of competing interests, ideas, values, views, ideologies, religions and cultures, a world full of conflicting interests on all levels, between individuals and groups of people within their societies, between all sectors of societies as well as between economies, nations, states and so forth. If we want to characterize our contemporary world it would be in many ways more appropriate to speak about a 'Clash of Interests' instead of Clash of Cultures (Fisher, 2000).

Inspite of the prevalence of disputes in modern society, there is some degree of consensus or agreement between individuals and groups solicited through processes of negotiation and compromise. If societal dispute was left uncontrolled, the whole world would have long disintegrated. According to conflict theorists (Fisher, 2000) there are several sources of disputes including economic, value and power. Economic dispute involves competing motives to attain scarce resources. Each party wants to get the most that it can to maximize net gains. Value disputes involve incompatibility in ways of life, ideologies the preferences, principles and practices that people believe in. Power dispute occurs when each party wishes to maintain or maximize the amount of influence that it exerts in the relationship and the social setting. Power conflict occurs between individuals, groups or nations

Over the last decade courts have developed rules that require parties to try Alternative Dispute Resolution mehanisms, usually mediation, before trial. Mandatory Alternative Dispute Resolution has become popular because it helps unclog the court system and because most cases can settle once the parties have undertaken discovery and understand what evidence exists. Uwazie (2011) however observed that despite numerous attempts at modernization, many African countries are still struggling to establish functional, timely, and trusted judicial systems. Most courts in Africa are fraught with systemic problems, such as antiquated structures. Countless judges still take notes by hand, as there are no stenographers. Re-cords are archived manually and a reliable computer in an African court is rare, especially at the magistrate courts that handle most cases. Many African citizens have lost faith in the ability of their nations' courts to provide timely or just closure to their grievances (Liebmann, 2000).

Dispute resolution refers to the processes by which disputes are brought to an end (Algert and Watson, 2002). Dispute is an open disagreement between two or more entities such as people, groups of people, 
ethnicities, nations, states and cultures who have different interests, goals and or values. Dependent on the intensity of the disagreement the dispute may gradually become a confrontation and finally a conflict. Dispute resolution can occur through three ways; negotiated outcome, where the parties concerned sort out things themselves: mediated outcome, where the parties use the services of an independent mediator to help them arrive at their own agreement and an arbitrated or adjudicated outcome, where an independent arbitrator or court determines how the dispute is to be resolved and makes a binding decision or order to this effect (Algert and Watson, 2002).

Alternative Dispute Resolution (ADR) is the general name given to a variety of procedures available to parties in civil cases to resolve their disputes before a formal trial (Lambert and Myers, 1999). Alternative Dispute Resolution refers to processes for resolving disputes other than litigation. Alternative dispute resolution (ADR) mechanisms have existed for thousands of years. Alternative dispute resolution (ADR) refers to any process or collection of processes established to resolve disputes without trial or violence. The term ADR is often used to refer to a broad category of ADR processes such as negotiation, conciliation, mediation, settlement conferences, arbitration, consensus building, and community conferencing.

Bungoma County is located in western and constitutes of Eight constituencies namely Mt Elgon, Kimilili, Webuye,Webuye North, Sirisia,Kabuchai, Kanduyi and Bumula. The capital of Bungoma County is Bungoma Town. It has a Total Population of 1,375,063 and covers an area of 3,032.2 sq. km. The Population density is 453.5 people per sq. $\mathrm{km}$ and $53 \%$ of the population live below the poverty line. The economy of Bungoma County is mainly agricultural, centering on the sugarcane and maize industries. The area experiences high rainfall throughout the year, and is home to several large rivers, which are used for small-scale irrigation.

Over the years Bungoma County has witnessed numerous conflicts ranging from land clashes in the Mt Elgon region, political violence linked to electoral processes, domestic violence, conflicts related to business transactions as well as labor unrest just to mention but a few. Investigation of the influence of the utility component of Alternative Dispute Resolution strategies will help inform sustainability of conflict resolution efforts (Chesi, 2012). Also, land conflicts has affected Mt. Elgon District in Bungoma county of Kenya. These land conflicts have had far reaching negative effects on the certainty of land markets, tenure and food security, economic production and reduction of poverty. Often, the land conflicts lead to; civil strife, loss of lives, population displacement, destruction of property and international humanitarian crisis (Chesi, 2012).

\subsection{Statement of the problem}

In post conflict and fragile contexts, where societal tensions are already high and justice systems typically do not function, the need for prompt resolution of disputes is particularly critical. Without timely, accessible, affordable, and trusted mechanisms to resolve differences, localized disagreements or crimes can degenerate into broader conflict (Algert, 1996). This contributes to cultures of violence and vigilante justice. There are recurrent conflicts despite efforts being put in place to address such conflict. The court systems are overwhelmed by a backlog of cases and have systemic challenges being brought about by corruption, poor infrastructure and inaccessibility that work to kill their efficiency. The choice of a good alternative dispute resolution strategy is a difficult task, because a lot of physical and mental energy is required (David, 2006). It is apparent that the success of a functional alternative dispute resolution strategy depends on good application using appropriate method which can subsequently motivate parties in dispute in their various communities. Lack of good alternative dispute resolution strategy by a trained individual in our community and institution can lead to inappropriate behavior and frustration. In making choice of alternative dispute resolution strategies communities are faced with the challenges of selecting the method suitable for achieving non (David, 2006).

Sustainable conflict resolution still remains a major challenge in Kenya and beyond. As noted by Murungi (1995), numerous conflict resolutions have been attempted, but none of them seems sustainable in creating an atmosphere for peace, security and inter-ethnic. Disputes keep recurring sometimes with greater intensity leading to widespread loss of life and destruction of property. This is despite the litigation processes in court systems and other alternative efforts being expended in addressing conflict. There is a disconnect between sustainable conflict resolution and the numerous efforts being put to use. Chesi (2012) did a study on the factors influencing land related conflicts in MT. Elgon District, Bungoma County. The study findings established that the severity of land conflicts in Mt. Elgon district is high and currently appear to be associated with geographical land boundaries, political boundaries, political environment and evictions from the land that they stay in. No study had been done on the influence of utilization of alternative dispute resolution mechanisms by leaders on sustainable conflict resolution in Kenya hence a research gap. This study therefore sought to investigate the influence of utilization of ADR mechanisms by the leadership on sustainable resolution of conflict in Kenya, a case study of Bungoma county.

\subsection{Objective of the study}

The specific objective of the study was; 
To determine the influence of mediation dispute resolution mechanism on sustainable conflict resolution in Bungoma County, Kenya.

\subsection{Research Question}

The study sought to answer the following question;

What is the influence of mediation dispute resolution mechanism on sustainable conflict resolution in Bungoma County, Kenya?

\subsection{Significance of the Study}

This research is vital to the conflict resolution teams in Bungoma County because it provides an insight on the utilization of alternative dispute resolution mechanisms by leaders on sustainable conflict resolution. The teams will be able acquire knowledge on the best approach to conflict resolution.

The results of this research are important to the Government of Kenya in the development of rules and procedures of solving conflicts arising within the country. Through the findings of this study, the policy makers can learn various ways in which they may need to handle conflict resolution and hence come up with policies that lead to sustainable conflict management and resolution.

The results of this study will greatly benefit the victims of conflicts in Bungoma County. It will increase awareness on the benefits of embracing Alternative Dispute Resolution Mechanisms and contribute to quick, timely and affordable administration of justice.

Future researchers will also be able to use the research findings as a benchmark to their research on conflict resolution. In addition, the findings of this study will serve as a source of reference in future research. The study has also suggested other areas where future researchers can further their knowledge.

\subsection{Literature Review}

This section discusses past studies on utilization of alternative dispute resolution mechanisms by leaders on sustainable conflict resolution.

\subsubsection{Empirical Review}

According to Uwazie (2011) the notion of ADR fits comfortably within traditional concepts of African justice, particularly its core value of reconciliation. Pioneering ADR projects in Ghana, Ethiopia and Nigeria have generated positive results and illustrate the suitability of ADR in African contexts.Under these arrangements, ADR was used as the default resolution method. Formal court litigation, or instances where the judge actually judges, are reserved for cases of constitutional or legal interpretation, where there is a need to set precedence, in cases with major public policy implications,or as a last resort after ADR has been tried.

\subsubsection{Mediation Dispute Resolution Mechanism}

Moore (2003) defines mediation as the intervention in a negotiation or a dispute of an acceptable third party who has limited or no authoritative decision- making power, who assists the involved parties to voluntarily reach a mutually acceptable settlement of the issue in dispute. Mediation is a process by which parties in conflict are helped to reach an amicable agreement by a neutral third party called a mediator. Mediation is a private and structured form of negotiation assisted by a third party that is initially non-binding. If a settlement is reached the mediator can draw up an agreement that can then become a legally binding contract. Moore (2003) points out that mediation finds its strengths through its privacy and confidentiality mode of operation, its voluntary and consensual obligations, its flexibility with rules and regulations, and its focus on interests and needs of the parties rather than the personalities behind the issues.

The meditator skillfully aids communication between the conflicting parties and helps them negotiate options to meet their interests, while preserving and repairing their relationship (Bennet \& Hughes, 2005). Mediation takes three models of transformative, facilitative or problem solving and evaluative mediation. These models have an important impact on the outcome of the process. An investigation of the role of the different mediation models on the outcome of a mediation process, though beyond the scope of this literature review is an aspect worth investigating (Bingham, \& Hallberlin, 2009). In the facilitative or problem solving mediation the neutral third party helps the parties identify their interest and focus discussions to brainstorm options that satisfy all of the parties interest. With evaluative mediation the neutral third party provides expert opinion on the merits of the dispute. The mediator helps the parties know the strengths and weaknesses of their case by providing them with an assessment, prediction and direction ((Bingham \& Hallberlin, 2009). In transformative mediation on the other hand, the meditator empowers the parties to control all aspects of the process, parties are helped in clarifying their interests, goal and choices and at the same time have a better understanding of the other party's perspective. The parties are transformed from positions of weakness to recognition of a possibility of mutual satisfaction of interests and settlement of the dispute (Bingham, 2004).

Moore (2003) notes that many governments and institutions including the United Nations have recognised that the costs of dealing with disputes within businesses, between individuals, in the family, and even 
internationally, using purely legal remedies only, are simply too high. Financial costs, emotional costs, and relational costs push the global perspective and the local variance of the same to see mediation as a major player within societal development.

There are three types of Mediatory methods proposed by Zumeta (2000) that seem practical for consideration, and Liebmann (2000) pinpoints these forms of mediation as being able to transform various situations of conflict. The first arm of mediation is the most common which is facilitative. In facilitative mediation, the mediator structures a process to assist the parties in reaching a mutually agreeable resolution. The mediator uses questions to bring out the parties points of view; searches for interests underneath the positions taken by parties; and assists the parties in finding and analyzing options for resolution. The facilitative mediator does not make recommendations to the parties; give his or her own advice or opinion as to the outcome of the case. The mediator is in charge of the process, while the parties are in charge of the outcome. Zumeta's (2000).

The Second type of mediation is the Evaluative mediation process which is usually modelled on settlement conferences held by judges. An evaluative mediator assists the parties in reaching resolution by pointing out the weaknesses of their cases, and predicting the legal likely result. In this style recommendations to the parties can be made, yet the decision is still in the hands of the individuals. Evaluative mediators are concerned with the legal rights of the parties rather than needs and interests, and evaluate based on legal concepts of fairness. This form of mediation is usually court oriented. The third postulation of Zumeta (2000) is that of Transformative mediation which is the newest of the three. Transformative mediation is based on the values of empowerment of each of the parties as much as possible, and recognition by each of the parties of the other parties' needs, interests, values and points of view. The potential for transformative mediation is that any or all parties or their relationships may be transformed during the mediation.

The findings of the research by Umunadi (2011) revealed that the mediation method can serve as the best method of alternative dispute resolution. The study further found out that mediation method was effective because it is a practical oriented method which accommodated different practical activities like flexibility in dialogue, confidentiality, privacy, neutrality, and reality test approach in dispute resolution. Ezeji (1993) highlighted the point that mediators utterances, actions, teaching methods, alternative dispute resolution strategies, leadership styles, knowledge of subject and skills in dispute resolution are considered as important factors having implication for non violent method of conflict resolution.

As part of a project on judicial reform, for example, Ghana held its first mediation week in 2003 in which about 300 cases pending in select courts in Accra were mediated over 5 days. Kimberlee Kovach (2011) noted that the effort was a major success, with 90 percent of surveyed disputants expressing satisfaction with the mediation proceess stating that they would recommend it to others.

The achievements of this initiative led to a follow up ADR round in 2007 where 155 commercial and family cases from 10 District courts in Accra were mediated over 4 days. Almost 100 cases were fully mediated or concluded in settlement agreements. Eighteen cases reached partial agreement and were adjourned for a later mediation attempt. A total of 37 cases were returned to court.

The 2007 program was expanded through 2008 and over 2,500 cases in seven district courts in Accra were mediated, with over 50 percent of the cases completely settled. This demonstrated both the scale and potential reduction in backlog that ADR can generate. More than 40 district courts in Ghana have since initiated courtconnected ADR programs.

In the ADR Center in the town of Ashaiman, for example, a group of five mediators settled 476 of 493 cases considered between January and June 2011. By 2013, all district, circuit, and high courts in Ghana will have functioning mediation programs, with a projection of 10,000 case mediations annually-signi ficantly reducing the pressure on Ghana's court system.

As noted by Kimberlee Kovach (2011) Ghana's positive experience with ADR greatly in-fluenced the creation of the country's landmark ADR legislation in 2010 - finalized after nearly 10 years of consultations, consensus-building, bill drafting, and multiple changes in government leadership and in the judiciary. ADR Act 798 is the most comprehensive ADR legislation in Africa. Under Section 82 of the law, mediation agreements are recognized as binding and enforceable as court judgments. The Ghana experience provides potentially useful lessons for other African countries contemplating ADR, especially regarding the importance of gaining official support and funding, establishing relationships between mediators and traditional chiefs to maximize the complementarity of their efforts, and instituting the enforceability of out-of-court settlements or mediation agreements.

Tosin Adejuwon(2009) writes that since the creation of the pioneering Lagos Multidoor Courthouse and its ADR Center in 2002, disputing parties now have the option of choosing among court-connected alternative methods to resolve their disputes, including the Lagos State Ministry of Justice's Citizen Mediation Centers $(\mathrm{CMC})$. Similar multidoor courts and CMCs either currently exist or are emerging in a dozen other locations in Nigeria, with an average of approximately 200 cases mediated monthly and resolution or settlement rates ranging from 60 to 85 percent. This represents a significant portion of caseloads in Nigeria where it is not 
unusual for judges to add up to 50 new cases to their docket each day.

Tosin Adejuwon(2009) also noted that in November 2009, in an effort to elevate and ex-pand the use of ADR as well as generate publicity and educate the legal profession, Lagos State held its first mediation week. About 100 medium-scale commercial disputes were selected from the Lagos Island High Court docket with the consent of disputants, lawyers, and judges and scheduled for mediation over 5 days. Using lessons learned from earlier experiences, nearly 60 percent of the mediations resulted in agreement. Over 98 percent of disputants surveyed expressed satisfaction with the process, and nearly 70 percent said they preferred mediation to court litigation. Most of the participating lawyers also found the process satisfactory and indicated that they would recommend it to their clients.

\subsubsection{Theoritical framework}

Various theorists have come up with theories on despute resolution. The theories adopted by this study include theory of process pluralism, theory of conflict and General Theory on Conflicts and Disputes. Theory of process pluralism points out that different kinds of matters may require different kinds of procedures or ways of dealing with the underlying conflict (Ralf, 1958) theory of conflict attempts to understand the different sources of conflict, the dynamics of how conflict develops, escalates or declines, and how conflict can be managed, reduced or resolved. Conflict theory tries to explain the types of conflicts that exist and whether they are productive or destructive and then goes on to attempt to explain the ways in which conflict proceeds or is structured and how it can be managed or resolved. The General Theory on Conflicts and Disputes assigns disputes to transitional and mature democracies and conflicts to authoritarian regimes (Otomar and Wehr, 2001). The First Premise of the General Theory is that there are no conflicts in democratic society, only disputes. The Second Premise is that in authoritarian regimes there are only conflicts and politicized systems of settlement, not disputes. The Third Premise is that in international relations, national states can transform conflicts into disputes. Conflicts are those issues that lack a legitimate, reliable, transparent, non-arbitrary forum for the peaceful settlement of differences (Otomar and Wehr, 2001). Disputes, conversely, are pre described as having recognized forums for their expression and resolution that meet the above criteria. In short, conflicts lack a viable containe" for the routine management of differences. A mature theory of dispute-resolution must encompass all institutions and processes - whether legal or non-legal, formal or informal, contemporary or customary - to further the end of settling disputes by smoothing away discords.

\subsection{Research Methodology}

This study adopted a descriptive research design. As noted by Cooper and Schindler (2000) descriptive research design are concerned with addressing the particular characteristics of a specific population of subjects, either at a fixed point in time or at varying times for comparative purposes. As noted by Gill and Johnson (2002), descriptive research design describes characteristics associated with the subject population. By using descriptive research design, the study was able to establish the how of the phenomenon under investigation. The target population of this study comprised of the dispute resolution leaders in Bungoma county. These are Members of County Assembly (MCA), religious leaders, County Commissioners, local chiefs and their assistants, village and clan elders, representatives of aid agencies, representatives of civil society groups, women leaders and leaders of the youth. These leaders were selected because of the role they play in dispute resolution.

The study selected a representative sample of 90 from the target population. Use of a sample enables the study to save cost and time. According to Pamela L.A \& Robert B.S (1995) experienced researchers regard a sample of 100 respondents as the minimum sample size and 1000 as the maximum sample size for large populations. They note that it is seldom necessary to sample more than 10 percent of the population to obtain adequate confidence.

The study used purposive sampling and simple random sampling to select a sample from the target population. Purposive sampling is a method in which elements are chosen based on purpose of the study. In this study purposive sampling was used to pick three Sub-Counties namely; Webuye, Cheptais and Lwandanyi because they are conflict flash points. Simple random was used to randomly sample the leaders in each of the selected Divisions. According to Mugenda and Mugenda (2003), simple random sampling is a sampling technique designed to ensure that every unit of a population has equal chances of being selected in the population. By use of simple random sampling in this study, a representative sample was obtained.

The data collection instruments that were used in this study are questionnaires and checklist of specific questions that were posed to key informants. As noted by Mugenda and Mugenda(1999), questionaires are appropriate for use when the target population is educated and knowledgeble. The questionaires were chosen for data collection in this study since the population of the study is well educated and also the questionaires save on cost and time. The questionnaire designed in this study comprises of two sections. The first part includes the demographic characteristics questions designed to determine the profile of the respondents while part two deals with the identified factors. The questionnaire has both open and close ended questions. The closed ended questions make use of a five point Likert scale where respondents were required to fill according to their level of 
agreement with the statements. The unstructured questions were used to encourage the respondents to give an indepth response where close ended questions are limiting.

A pilot study was conducted to test for clarity and understanding of questions and also to find out whether the questions yield the answers expected. The researcher selected a pilot group of 5 individuals from the target population.

The study used both face and content validity to ascertain the validity of the questionnaires. Content validity was employed by this study as a measure of the degree to which data collected using a particular instrument represents a specific domain or content of a particular concept.

Reliability was assessed using the split half reliability method. Reliability is said to be stable if it gives consistent results with repeated measurements of the same object with the same instrument. The degree of stability is determined by comparing the results of repeated measurements. The split half method involves scoring two-halves of a test separately for each person and then calculating a correlation coefficient for the two sets of scores. The researcher split the instrument into two halves. The researcher got a coefficient of 0.70 which implies that there is a high degree of data reliability.

Kothari (2004) views data analysis as the whole process, which starts immediately after data collection and ends at the point of interpretation and processing of results. The quantitative data collected using questionnaires and interview schedules will be inspected for completeness, and analysed using Statistical Package for Social Sciences (SPSS v. 21.0). The results were presented in form of tables and graphs.

\subsection{Findings}

Research findings are presented in this section.

\subsubsection{Questionnaire return rate}

Out of 90 questionaires administered to 90 leaders in three sub counties of the larger Bungoma County,85 were returned making questionaire return rate to be $94 \%$.

\subsubsection{Demographic information of the respondents}

This study sought information from male and female leaders of diverse age groups. This was aimed at ensuring that all leaders regardless of the age participated in the study.

\section{Table 1: Age of the respondents}

\begin{tabular}{lll}
\hline & Frequency & Percent \\
\hline $25-35$ & 6 & 6.7 \\
$35-45$ & 26 & 28.9 \\
$45-55$ & 36 & 40.0 \\
$55-65$ & 21 & 23.3 \\
65 and older & 1 & 1.1 \\
& & \\
\hline Total & $\mathbf{9 0}$ & $\mathbf{1 0 0 . 0}$
\end{tabular}

The Table shows that $40 \%$ of the respondents were aged between $46-55$ years and that those aged between $36-45$ years accounted for $28.9 \%$ of those interviewed. Those aged between $26-35$ years accounted for $6.7 \%$ while those between 56-65 years stood at 23.3\% The leaders who indicated that they were 65 years and above stood at $1.1 \%$ of the entire sample.

In terms of gender, $86.7 \%$ of the interviewed were men while $13.3 \%$ were women. In Luhya ,Teso and Saboat cultures women have not been readily accepted as capable leaders and have therefore been largely excluded from grass root leadership. Most village and clan elders are men hence the small number of women respondents. It is vital to note that the 2010 constitution gives both men and women equal opportunity in all spheres of social,political and economic being of our country. Therefore nobody should be discriminated or denied leadership opportunities on account of their gender. Women must rise to challenge these dicriminatory tendencies and play an active role in the leadership of their communities.

Table 2: Gender of the respondents

\begin{tabular}{llll}
\hline & & Frequency & Percent \\
\hline \multirow{2}{*}{ Valid } & Male & 78 & 86.7 \\
& Female & 12 & 13.3 \\
\hline \multirow{2}{*}{ Total } & & $\mathbf{1 0 0 . 0}$ \\
\hline
\end{tabular}


The respondents were asked to indicate their marital status, this was aimed at establishing whether marital status has a bearing on whether an individual is given leadership roles or not including conflict resolution.

Table 3: Marital status of the respondents

\begin{tabular}{cccc} 
& & & Fercent \\
& & Frequency & \\
\hline \multirow{2}{*}{ Valid } & Married & 86 & 95.6 \\
& Single & 4 & 4.4 \\
\hline & Total & $\mathbf{9 0}$ & $\mathbf{1 0 0 . 0}$
\end{tabular}

This study indicates that $95.6 \%$ the respondents are married while a mere $4.4 \%$ are single an indication that the local communities place value on family life and thus require their leaders to be marry before taking on leadership roles. This however, needs to change so that leadership is not pegged on marital status. It is discriminatory and unconstitutional

The respondents were asked to indicate their level of education, this was aimed at establishing whether education is a factor that hinders people from executing their leadership responsibilities including conflict resolution.

Table 4: Education of the respondents

\begin{tabular}{llll}
\hline & & Frequency & Percent \\
\hline \multirow{4}{*}{ Valid } & .00 & 1 & 1.1 \\
& Primary & 3 & 3.3 \\
& Secondary & 43 & 47.8 \\
& Tertiary & 33 & 36.7 \\
& University & 10 & 11.1 \\
\hline & & & \\
\hline
\end{tabular}

This study indicates that literacy levels among leaders in Bungoma County is high with $47.8 \%$ of the sampled leaders having attained secondary education,36.7\% had gone through tertiary institutions while holders of university degrees stood at $11.1 \%$. This therefore shows that the leaders have the requisite education and capacity to execute their functions including conflict resolution.

The question on whether the leaders were born and raised in their area of jurisdiction or they immigrated in to the area was also posed to the respondents. This was aimed at ensuring that the respondents understand the area they work in and the conflict issues at hand. $77.8 \%$ of the respondents said they were born and raised in their areas of jurisdiction. $15.6 \%$ of the respondents migrated into their current areas of residence while $2.2 \%$ of the sampled respondents were born in their areas of residence but were raised elsewhere. This is a clear indication that most of the sampled leaders know their areas well and have a grasp of the issues that cause conflict.

From the study it was also established that $80 \%$ of the respondents have lived in their areas of jurisdiction all their lives while $11.1 \%$ indicated that they had lived in their areas of residence for Ten years or more. Only $7.8 \%$ of the responding leaders said they had lived in their areas for more less than five years. The length time lived in area has a bearing on a person's understanding of not just the area and its people but also the issues affecting them.

This question was posed to respondents with a view to establish whether or not they had worked in the public sector as government employees. Experience in the public sector especially in volatile areas gives an officer opportunity to handle and manage conflict. It affords such officers an opportunity to understand conflict resolution including alternative dispute resolution mechanisms. This experience works to equip the officers with knowledge and skills in the execution of their responsibilities to the public.

As shown in Table 5, 50\% of the respondents reported that they have never worked in the public sector as government employees while $44.4 \%$ reported to have worked in the public sector. The $50 \%$ however explained that they are village and clan elders who work alongside public servants especially chiefs and County 
Commissioners. Five respondents did not answer this question.

Table 5: Whether or not leader had worked in public service

\begin{tabular}{llll} 
& & Frequency & Percent \\
\cline { 3 - 4 } & & & 3.3 \\
\multirow{4}{*}{ Valid } & Yes & 3 & 44.4 \\
& No & 40 & 50.0 \\
& 7.00 & 2 & 2.2 \\
\hline & Total & $\mathbf{9 0}$ & $\mathbf{1 0 0 . 0}$
\end{tabular}

The dominant tribes in Bungoma Countyy are the Bukusu and the Sabaot accounting for $70 \%$ and $24 \%$ of the County population respectively. The Kikuyu,Teso,Tachoni and other tribes account for only $6 \%$ of the County population.This percentages explain the antagonism between the Bukusu and Saboat over land ,distribution of jobs and development resources.

In Lwandanyi and Cheptais Sub-Counties,this conflict is pronounced because of these two dominant tribes.The Saboats mainly inhabit the Cheptais area and the greater Mt. Elgon . The Saboat accuse the Bukusu of dominating them by taking most of the political and state leadership positions because of their superior population numbers. This fights led to the creation of Mt. Elgon constituency so that the Sabaots can have their own member of parliament to champion their grievances.

The Bukusu on the other hand accuse the Sabaot of alleniating themselves and identifying with the Kalenjin in the Rift Valley a fact that was always visible during elections where the Saboat voted to support the presidential candidate fronted by the Kalenjin community.

Table 6: Intermarriage among communities

\begin{tabular}{llll}
\hline & & Frequency & Percent \\
\hline \multirow{3}{*}{ Valid } & .00 & 2 & 2.2 \\
& Yes & 85 & 94.4 \\
& No & 3 & 3.3 \\
\hline & & & $\mathbf{1 0 0 . 0}$
\end{tabular}

Communities in Bungoma County intermarry freely. 94.4\% of the sampled respondents indicated that there's free intermarriage among tribes residing in their Sub-Counties. A negligible 3.3\% responded to the contrary.However, this has done little to prevent conflict over land resource allocation in the County an indication that there is significant political undertones in the conflicts.

1.9.3 Inter community conflicts.

$37.8 \%$ of the respondents indicated that conflict mostly occurs between the Bvukusu and the Sabaot while $2.2 \%$ said the conflict they have witnessed is between the varrious Sabaot clans.23.3\% indicated that there is conflict between the Bukusu and the Tachoni mainly in Webuye Sub-County. The conflict between the Bukusu and the Sabaot mainly occurs in Cheptais and Lwandanyi Sub-Counties.This is so because the two communities have historically occupied these area but the Sabaots have mostly occupied the upper areas of mount Elgon.

The conflicts mainly revolve around land and distribution of resources including state jobs. From my discussions with area residents it emerged that the fight between the Bukusu and Sabaots over land is historical in nature. The sabaots were not farmers but hunters and gatherers mainly leaving in caves in the expansive mt. Elgon area while the Bukusu have always been a farming community. After the departure of white settler farmers from the high potential areas of the mountain the Sabaots laid claim to the land sparking of a violent conflict with the Bukusu community.

Government failure to address land problems in the area and political interference in the process also led to fighting between various Sabaot clans. The Moi government issued land to some clans while others were left out of the scheme.This fueled conflict.It is also notable that many Sabaots were evicted from the mt. Elgon forest rendering many as squarters. This also fueled the conflict and led to the formation of the infamous Sabaot land defence force(SLDF) by disgrantled clans to fight for their rights. The S.L.D.F may have been crushed by brute military force but the land grievances still exist and remain unaddressed. 
Despite the violent conflict in Mt. Elgon pitting the various Sabaot clans against each other being highlighted in the media and the swift and brutal government response, it is important to note that the Sabaot speak one language and have historically lived in peace.This is why only $2.2 \%$ of the respondents highlighted this conflit.

In this study, $23.3 \%$ of the respondents indicated that there's a conflict between the Bukusu and the Tachoni communities mainly in Webuye Sub- County.My interactions with the local communities in Webuye revealed long standing rivalry between the two communities dating to pre-colonial times. The Tachoni have always accused the Bukusu of deliberate attempts to dominate and lock them out of political leadership.

To reinforce this fact Tachoni clan elders point to the fact that during colonial times a Bukusu chief was imposed on them and this domination was continued after independence when the Bukusu always grabbed the only parliamentary position available because of their superior numbers. The Tachonis have since felt marginalised. To express their disatisfaction,the Tachoni have always sponsered and voted for one of their own in every election. This injustice has since been addressed following the creation of Webuye North Constituency following the revision of constituency boundaries in Kenya just before the 2013 general election that led to the splitting of the former Webuye constituency.

Village elders ,clan elders and religious leaders featured prominently in this study because they are readily available and intimately understand the issues that cause conflict in their communities. Village elders, for example, play a crucial role in providing linkage between the community and government structures as well as actively participate in addressing conflict.

Political leaders such as members of parliament and Members of County Assembly though crucial in conflict issues were unavailable and efforts to reach them were futile because of their busy schedule.

Table 7: Leadership position currently held

\begin{tabular}{lll}
\hline & Frequency & Percent \\
\hline clan elder & & \\
\hline village elder & 13 & 14.4 \\
county commissioner & 15 & 16.7 \\
Member of county assembly & 23 & 25.6 \\
Civil Society representative & 3 & 3.3 \\
Aid agency representative & 6 & 6.7 \\
Religious leader & 2 & 8.9 \\
Youth Leader & 11 & 2.2 \\
County Rep & 2 & 12.2 \\
14.00 & 3 & 2.2 \\
27.00 & 1 & 3.3 \\
28.00 & 1 & 1.1 \\
57.00 & 1 & 1.1 \\
& 1 & 1.1 \\
Total & & 1.1 \\
\hline
\end{tabular}

The study also sought to find out how long the leaders had served in a bid to establish their understanding of local issues and conflict dynamics in their areas. $40 \%$ of the leaders indicated that they had served for more than 15 years while $20 \%$ and $30 \%$ of the leaders have been in service for 15 years and 10 years respectively. It is clear that the leaders have a clear understanding of the conflict issues in their areas of jurisdiction by virtue of length of service. 


\subsubsection{Frequency of conflict}

Table 8: Frequency of Conflict

\begin{tabular}{|c|c|c|}
\hline & Frequency & Percent \\
\hline .00 & 3 & 3.3 \\
\hline Fairly frequent & 14 & 15.6 \\
\hline Valid Not frequent & 30 & 33.3 \\
\hline Very Frequent & 2 & 2.2 \\
\hline
\end{tabular}

After every electoral cycle

$41 \quad 45.6$

\begin{tabular}{lll}
\hline Total & 90 & 100.0
\end{tabular}

The study also sought to establish the frequency of conflicts and as shown in Table 4.4.6, 45.6\% of the respondents reported that conflicts arise after every electoral cycle. $33.3 \%$ of the respondents said the conflicts though present, are not frequent while $15.6 \%$ of the sampled leaders said the conflicts are fairly frequent. In Kenya, elections are always associated with violence and it is not surprising that $45.6 \%$ of the sampled leaders in Bungoma County said the conflicts arise during and after elections. Politicians use violence to influence the outcome of elections.

The frequency of conflict especially around election time is an indication that politics is a major factor in the triggering of conflict in the County. Politicians take advantage of community grievances concerning land and distribution of development resources to whip up emotions and even sponsor violence for personal gain. In my discussion with leaders in the sampled sub- Counties it emerged that prior to elections the Sabaot leaders in $\mathrm{mt}$ Elgon cause tension to trigger mass exodus of the Bukusu so that they do not vote and tilt scales in favour of particular candidates.

\subsubsection{Mediation}

Table 9: Utilization of Mediation

\begin{tabular}{|c|c|c|c|}
\hline & & Frequency & Percent \\
\hline & Yes & 86 & 95.6 \\
\hline \multirow[t]{3}{*}{ Valid } & No & 2 & 2.2 \\
\hline & 4.00 & 2 & 2.2 \\
\hline & Total & 90 & 100.0 \\
\hline
\end{tabular}

As indicated in Table 9, it is clear that mediation has been embraced by leaders in their conflict resolution efforts in Bungoma County. This is because $95.6 \%$ of the sampled leaders indicated that they assist parties involved in disputes to voluntarily reach a mutually acceptable settlement on the issues in dispute. They also reported to using their influence to secure amicable agreement among disputants. This is crucial for sustainable peace because each of the parties leaves satisfied with the outcome of the mediation process.

The sharing of political leadership positions, plum county jobs and development resources is bound to create tension and as such the leaders intimated that round table discussions among leaders from rival communities and camps are organized and led by respected neutral third parties who lead the groups towards amicable agreements. It was claimed during my discussions with various sampled leaders that such meetings were held between the Bukusu and the Sabaot political leaders where an agreement was struck to have the Bukusu take the gubernatorial seat while the sabaot take the deputy governor's position. The leaders said this is what averted a conflict between the Bukusu and the Sabaot in the last election. It is important to note that Hon. Kenneth Lusaka the governor of Bungoma County comes from the Bukusu community while his deputy is from the Sabaot community. 
1.9.6: How leaders use mediation to resolve conflicts

Table 10: How leaders use mediation to resolve conflicts

\begin{tabular}{lll}
\hline & Frequency & Percent \\
\hline Yes & 1 & 1.1 \\
Valid & 82 & 91.1 \\
No & 4 & 4.4 \\
3.00 & 2 & 2.2 \\
23.00 & 1 & 1.1 \\
\hline Total & & $\mathbf{1 0 0 . 0}$
\end{tabular}

As shown in Table 10, 91.1\% of the respondents said that in their use of mediation, the process is sometimes private but is mostly an open/public and structured form of negotiation assisted by a third party that is initially non-binding but if a settlement is reached the neutral third party can draw up an agreement that can then become a legally binding contract.

$4.4 \%$ of the respondents said that in handling disputes using mediation, the process is an open/public and unstructured form of negotiation assisted by a third party that is initially non-binding but if a settlement is reached the neutral third party can draw up an agreement that can then become a legally binding contract.

Another $1.1 \%$ of the respondents on the other described their mediation process as a private and structured form of negotiation assisted by a third party that is initially non-binding but If a settlement is reached the neutral third party can draw up an agreement that can then become a legally binding contract.

The analysis above indicates that more leaders have embraced mediation processes that are public and structured as well as the use of neutral third parties that command respect from parties to the dispute. It is vital that a mediator be neutral and objective for sustainable conflict resolution. Sharing of political power, land and development resources are emotive issues and must be handled with care to avoid a recurrence of conflict that mostly turns violent when poorly handled. In Bungoma County, i was informed that once such agreements are secured, it is incumbent on the parties to jointly market the agreements to their communities and project unity for the agreements to hold.

Table 11:

Whether or not mediation processes are kept private and

confidential

\begin{tabular}{lll}
\hline & Frequency & Percent \\
\hline .00 & 2 & 2.2 \\
Yes & 70 & 77.8 \\
Valid & 15 & 16.7 \\
NO & 3 & 3.3 \\
3.00 & $\mathbf{9 0}$ & $\mathbf{1 0 0 . 0}$
\end{tabular}

$77.8 \%$ of the respondents reported that while using mediation to resolve conflict they keep the process private and confidential while $16.6 \%$ reported to keeping the processes open to all. Some respondents did not answer this question. This question was posed to the respondents to test their grasp of the mediation process and to find out how the leaders in Bungoma County use mediation in resolving conflict.

Those leaders who keep the mediation processes private and confidential intimated that this is done to keep the acrimony of negotiations out of the public and only open up the process once an agreement has been struck. They argued that land issues and sharing of political power are sensitive issues that take time to resolve and therefore must be discussed in privacy where negotiators are encouraged to be open and candid with each other regarding the sticky issues. Many times there are stalemates and hurdles that will only be broken with sober discourse which is only possible in an environment that is without pressure. 
The study also established that $94 . \%$ of the sampled leaders keep mediation processes voluntary, consensual and flexible while $6 \%$ said they dont. This question was aimed at establishing whether or not the leaders understand the vitality of free will, voluntary participation and flexibility in mediation processes. For any mediation process to succeed the parties must voluntarily participate without undue influence or pressure. The process should also be flexible and must adapt to changing circumstances and realities.

Table 12: The focus of mediation processes

\begin{tabular}{lcl}
\multicolumn{2}{c}{ Frequency } & \\
\hline \\
Yes & 82 & Percent \\
No & 8 & 91.1 \\
\hline Total & 90 & $\mathbf{1 0 0 . 0}$
\end{tabular}

Table 12 shows that $91 \%$ of the sampled respondents ensure that the mediation processes focus on interests and needs of the parties in conflict rather than the personalities behind the issues. $9 \%$ of the sampled leaders think the personalities behind the issues should not be ignored.

This question was also designed to test understanding of the mediation process by the concerned leaders.91\% of the respondents said it was important that the interests and needs of the parties be given adequate attention. This they said is important because personalities come and go but issues if not addressed have the tendency to escalate into violent conflict.

The sharing of political power, land and development resources among communities are sticky issues in Bungoma County and it is vital that this issues are addressed regardless of the personalities championing them. During my interviews with various leaders in the County i learnt that there is a simmering conflict with regard to the sharing of executive positions in the County government.

The Bukusu clans in Kanduyi, Bungoma South and Webuye Sub-Counties accuse the governor and his deputy of appointing people from Kimilili and Mt. Elgon Sub- Counties to the plum positions while sidelining the other areas. This conflict has since been taken to court and it is notable that the High court sitting in Bungoma recently nullified the appointments. The governor of Bungoma County has since appealed against that decision but it is yet to be resolved.

Table 13: Whether or not third parties aid communication between disputants

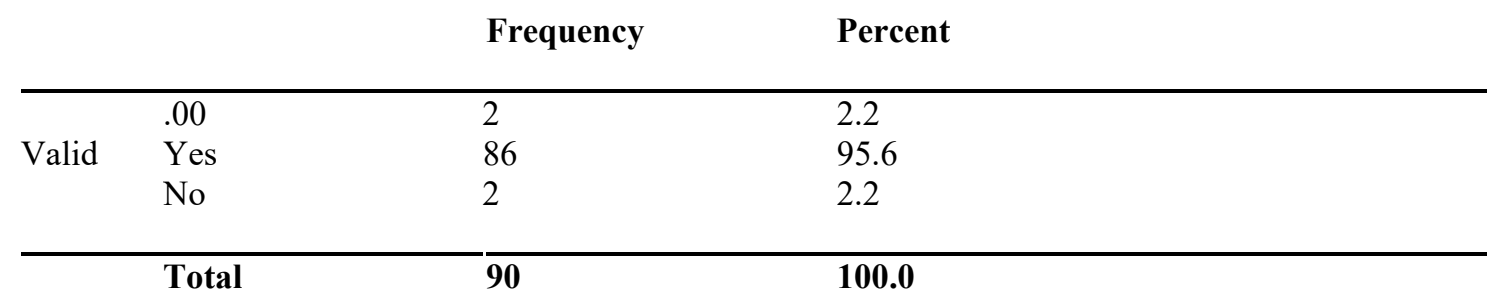

Table 13 shows that $95.6 \%$ of the sampled respondents indicated that in the discharge of their conflict resolution duties they skillfully aid communication between the conflicting parties. It is important that communication between the parties be done in such a way that it enhances understanding of each others' point of view.Mediators have a responsibility to ensure that parties bring out their issues clearly so that they can be addressed and this helps move the parties towards a solution.

This question was designed to gauge the understanding of the nitty gritties of the mediation process and its use by the leaders in their conflict resolution duties. The high percentage of respondents affirming the aiding of communication between the parties in a mediation process is an indicator of not only the understanding but also of the practice of this important aspect of mediation.

1.9.7 Whether third parties support parties negotiate options to meet their interests while preserving and repairing their relationship.

Most of the respondents (96\%) interviewed for this study felt that for mediation processess to succeed,it is important for neutral third parties taking charge of the process to support conflicting parties negotiate options that meet their interests while at the same time repairing their relationship. The communities living in the County need each other for prosperity. Their lives are intertwined and depended on one another. The communities share 
schools, markets, Banks,roads, health facilities and even human resources. It also emerged that there are kinship ties across communities because of intermarriage. There are many Bukusu women married to Sabaots and vice versa.This is also true for the Bukusu andd the Teso as well as the Bukusu and the Tachoni.

The leaders interviewed said that whenever conflicts occur they always take time to remind the parties that they are brothers who need each other in the long term and should therefore have foresight in their agreements.

\subsubsection{Provision of expert advise/opinion on the merits of the dispute by neutral third party}

This study revealed that $93 \%$ of the respondents provide expert opinion on the merits of the dispute in question while $4 \%$ of the respondents said they dont, $3 \%$ of the respondents skipped this question. Further probing of the leaders who provide expert opinions on disputes showed that these was only applicable in issues concerning land. They said they understand land issues deeply because most of them are locals who sit on local land control boards in their respective sub- Counties. This question was also designed to test the understanding and use of mediation by the local leaders.

Table 14: Provision of by neutral third party

$$
\text { expert advise/opinion on the merits of the dispute }
$$

\begin{tabular}{lll}
\hline & Frequency & Percent \\
\hline .00 & 2 & 2.2 \\
Yes & 84 & 93.3 \\
No & 4 & 4.4 \\
& & \\
\hline Total & $\mathbf{9 0}$ & $\mathbf{1 0 0 . 0}$
\end{tabular}

The study also revealed that $98 \%$ of the respondents assist parties in conflict to know the strengths and weaknesses of their case by providing them with an assessment, prediction and direction concerning the issues in dispute. This they said is important in speeding up the process so as to arrive at amicable solutions. The high number of respondents agreeing with such assessment, prediction and direction concerning sticky issues is an indicator of use and understanding of mediation.

Table 15: Showing neutral third party role in empowering the parties to control the dispute resolution process.

\begin{tabular}{lll}
\hline & Frequency & Percent \\
\hline .00 & 1 & 1.1 \\
Yes & 84 & 93.3 \\
No & 5 & 5.6 \\
\hline Total & $\mathbf{9 0}$ & $\mathbf{1 0 0 . 0}$
\end{tabular}

As indicated in table $15,93 \%$ of the sampled respondents reported that in the course of their conflict resolution duties, they empower the parties in conflict to control all the aspects of the dispute resolution process,including helping the parties clarify their interests, goal and choices.Only $6 \%$ of the sampled respondents thought otherwise. Those who go out of their way to help parties clarify their goals and interests said they considered it their responsibility as leaders to do this so as to ensure justice is achieved.They however lamented the lack of goodwill and support from government in terms of capacity building,establishment of structures for dispute resolution at grassroot level and remuneration for community leaders. Those who said they do not help parties clarify their goals and interests said they lacked capacity and only provide a condusive environment for fruitful negotiations. 
Table 16:Use of questions to bring out the parties' points of view; search for interests, find and analyze options for resolution

\begin{tabular}{|c|c|c|}
\hline & Frequency & Percent \\
\hline$\overline{\text { Yes }}$ & 89 & 98.9 \\
\hline No & 1 & 1.1 \\
\hline
\end{tabular}

The use of questions to bring out the parties points of view; search for interests underneath the positions taken by parties; and assistance to parties in finding and analyzing options for resolution was strongly advocated for by the respondents in this study. As a matter of fact, $99 \%$ of the respondents said they employ this strategy in their execution of conflict resolution resolution duties.

These respondents pointed out that questions help clarify issues and enable mediators understant the borne of contention in the matter at hand.Specific questions are posed to ensure disputants are following the process and agree or disagree with its progress. This gives mediators an opportunity to be in control of the process.Most respondents also mentioned that questions help eliminate issues that may be unnecessary in the mediation process and thus helps save time.

Formal training to equip leaders with competencies to effectively perform the responsibilities of a neutral third party was mentioned as being very important for mediation. $84 \%$ of the sampled respondents said they had benefited from formal training in this regard.Only 14\% of them said they had not been trained.Those that had been trained said they had attended training meetings at their respective Sub-County headquarters where they were lectured the importance of impartiality in mediation. They also learnt listening and facilitation skills. When asked about who facilitated the training and how long it took many said they had been trained by Officers in the County Commissioners' office and that the training had lasted one day.

It is vital to note that such trainings are ineffective because of their poor quality.Conflict resolution and management has many issues that must be addressed in the content of such trainings and it is highly unlikely that a one day training is adequate.It is also important that such content be tailored to the needs of specific areas while taking into consideration the unique circumstances of each area. It is notable that most of the leaders who underwent this training do not have reference material or guidelines for mediation a pointer to the poor quality of the said training exercise.

\subsubsection{Frequency of recurrence of disputes addressed through mediation.}
Table 4.5.9
showing
frequency of recurrence of
disputes addressed through mediation.

\begin{tabular}{llll}
\hline & & Frequency & Percent \\
\hline .00 & & 1 & 1.1 \\
Valid & Rarely recur & 55 & 61.1 \\
& $\begin{array}{l}\text { recur every } \\
\text { especially } \\
\text { elections }\end{array}$ & $\begin{array}{l}\text { years } \\
\text { during } 34\end{array}$ & 37.8 \\
\hline & Total & $\mathbf{9 0}$ & $\mathbf{1 0 0 . 0}$
\end{tabular}

With regard to recurrence of disputes addressed through mediation, $61 \%$ of the sampled leaders said that such disputes rarely recur while $38 \%$ said such disputes recur every five years especially during elections. Those who said the disputes rarely occur were however clear that such disputes are those land disputes between individuals and are far in between. Those who said the disputes recur every five years especially during elections made reference to community land disputes. These they said are common place between the Bukusu and the Sabaots in Cheptais and Lwandanyi Sub-Counties and are mostly fueled by politicians.

\subsubsection{Disputes resolved through mediation}

According to the leaders sampled in this study,land disputes form the bulk of the disputes solved through mediation by leaders in the County accounting for $60 \%$ of the cases. Disputes over sharing of political leadership positions account for $10 \%$ of the cases while disputes arising out of unequal distribution of development resources only account for $7 \%$ of the cases. Other respondents provided more than one answer to this question. A further probe into why the land disputes featured prominently in cases handled by leaders through mediation 
reaved that the County had huge chunks of land that had not be registered and therefore lacked title deeds. This the leaders said was the reason behind quarrels over land ownership. They squarely blamed the government lands ministry for this failure.

When asked why mediation had taken center stage in land issues the leaders said residents were facing frustration with court litigation processes that are too slow and expensive with many land cases taking more than 20 years to resolve. Disputes arising out of unequal distribution of development resources and sharing of state jobs were said to be handled by members of parliament and leaders in senior positions in government and only featured at the grassroots when members of parliament complain publicly at official functions to galvanize support and secure development support for the County.

The leaders pointed to a case where the then former Bumula Member of parliament told President Mwai Kibaki at a pubic rally at Kanduyi stadium in the year 2009 that despite voting for the ruling party the people of Bungoma County were yet to see a person from the County appointed to a senior position in goverment. He also pressured the president to tell the residents when Kibabii University College would be built. It is noteworthy that Kibabii University College has since been built.

\subsection{Conclusion}

Alternative dispute resolution mechanisms are an important component in the justice system of a country. They provide opportunity and space for parties in conflict to resolve the issues in contention amicably while avoiding the costs and delays associated with normal court processes.

This study established that though ADR mechanisms are in use at the community level, County governments have not put in place mechanisms to institutionalise ADR. There are glaring capacity gaps that continue to impact on the adoption and use of ADR mechanisms. This must be addressed.

\subsection{Recommendations.}

In order to address land disputes emanating from lack of clear ownership, the lands ministry needs to improve the quality of service delivery to the citizens of Bungoma County. Rampant corruption perpetuated by officers at the lands office was cited as am major stumbling block in acquisition of land title deeds and must be stopped.

Land allocations in the former white settler areas of $\mathrm{mt}$. Elgon have been infiltrated by political interests and this is the root cause of unrest in Mt. Elgon Sub-County. The national and County government must take decisive action to address the land grievances of the Sabaot community to stop the inter clan fighting that has led to loss of many lives and massive destruction of property.

\section{REFERENCES}

Algert, N.E. (1996). "Conflict in the workplace" in Proceedings: Women in Engineering Advocates Network, Denver, CO., 123-127.

Berg, W., \& Gall, M. (1989).Educational research: An introduction. New York: Longman

Bingham, L. B. (2004). Employment Dispute resolution: The case for mediation.Conflict Resolution Quartely,22(1-2), 145-174.

Bingham, L. B., \& Hallberlin, C. J. (2009). Dispute System Design and Justice in Employment Dispute Resolution: Mediation at the Workplace. Harvard Negotiation Law Review,14(1), 1-50

Blake, S., Browne, J., \& Stuart S. (2011). A practical approach to alternative dispute resolution. Oxford University Press Inc.: New York

Chesi, A. S. (2012). Factors influencing land related conflicts in MT. Elgon District, Bungoma County. Unpublished MBA thesis University of Nairobi.

Fisher, R., \& William, U.(2011). Getting to yes: Negotiating agreement without giving In. Penguin Books ltd: London

Hornby A.S. (2006). Oxford Advanced Learner's Dictionary. India: Oxford University Press.

Pamela L. A \& Robert B. S(1995). The survey research handbook, University of Wisconsin,Madison, 2nd edition,

Kothari, C. R. (2004), Research Methodology: Methods and Techniques. New Delhi:Wiley

Lacity, M., \& Jansen, M. A. (1994). Understanding qualitative data: A framework of text analysis methods. Journal of Management Information Systems, 11, 137-166.

Lambert, J., and Myers, S. (1999). 50 Activities for conflict resolution. Amherst, MA: HR Development Press.

Liebmann, M. (2000). Mediation in context. Jessica Kingsley Publishers Ltd: London.

Mugenda. O. A. and Mugenda A. G. (1999). Research methods: Quantitative and Qualitative approaches, Nairobi, Act Press

Ngechu.M. (2004), Understanding the research process and methods.An introduction to research methods. Acts Press, Nairobi

Polkinghorne, D. (1988). Narrative knowing and the human sciences. Albany: State University of New 
York Press.

Otomar, J. B., and Wehr, P. (2001). Using Conflict theory. Press syndicate publishers. Newyork.

Ralf, D. (1958). Toward a Theory of Social Conflict. The Journal of Conflict Resolution, Vol. 2,No. 2. pp. 170183

Umunadi, E. K. (2011). The Efficacy Of Mediation and Negotiation Methods For Dispute Resolution In Delta State, Sacha Journal of Policy and Strategic Studies, Volume1Number 2, pp. 64-73

Uwazie, E. E. (2011). Alternative Dispute Resolution in Africa: Preventing Conflict and Enhancing Stability.African Security Brief, 1-6.

Zumeta, Z. (2000). Styles of mediation: Facilitative, evaluative, and transformative mediation'. 